\title{
Incomplete Penoscrotal Transposition in a Boy with Prenatally Diagnosed Klinefelter Syndrome: Case Presentation and Review of the Literature
}

\author{
Teresa Dudek - Warchol, Stanislaw Warchol* \\ Department of Pediatric Surgery and Urology, Medical University of Warsaw, Warsaw, Zwirki\&Wigury street \\ 63 a: Poland
}

*Corresponding Author: Stanislaw Warchol, Department of Pediatric Surgery and Urology, Medical University of Warsaw, Warsaw, Zwirki \& Wigury street 63 a: Poland, E-mail: swarchol@poczta.onet.pl

\begin{abstract}
Klinefelter syndrome characterized by hypergonadotropic hypogonadism, gynecomastia and azoospermia, with characteristic male karyotype 47,XXY, represents the most common major abnormality of sexual differentiation as well as and form of infertility. The syndrome is diagnosed more frequently in an adolescent or adult patient. Genital anomalies are generally not recognized as associated features. Newborns with Klinefelter syndrome usually present normal male phenotype and the only abnormal clinical symptom are small testes; however, this is recognized usually after puberty. Prepubertal diagnosis of Klinefelter syndrome, especially due to genital malformations, is a rare entity. We present a boy with prenatally diagnosed Klinefelter syndrome concomitant with penoscrotal transposition. Review of the literature on the subject is enclosed.
\end{abstract}

Keywords: Klinefelter syndrome, hypergonadotropic hypogonadism, penoscrotal transposition, prepubertal diagnosis, prenatal diagnosis

\section{INTRODUCTION}

Klinefelter syndrome with characteristic male karyotype 47, XXY, represents the most common major abnormality of sexual differentiation as well as any form of infertility. The typical presentation is an adolescent or adult patient with hypergonadotropic hypogonadism, gynecomastia, azoospermia, increased gonadotropin levels and small, firm testes [1,2].

Most cases are diagnosed after puberty $[3,4,5$, 6]. Genital anomalies are generally not recognized as associated features [5, 7, 8]. Prepubertal diagnosis of Klinefelter syndrome, especially due to genital malformations, is a rare entity [9].

The aim of this report is to present a boy with prenatally diagnosed Klinefelter syndrome concomitant with penoscrotal transposition. Review of the literature on the subject is enclosed.

\section{CASE REPORT}

2-month old boy with prenatally diagnosed Klinefelter syndrome (amniocentesis with kariotyping performed because of hypotrophia of the fetus as well as prenatal ultrasound results suggestive of abnormal external genitalia) was referred for urological evaluation because of ambiguous genitalia (Figure $1 \mathrm{a}, \mathrm{b}$ ). After birth small VSD was diagnosed, which closed spontaneously during follow-up. On physical examination partial penoscrotal transposition, bifid scrotum and bilateral scrotal hernia were noted. Abdominal ultrasound was unremarkable, scrotal ultrasound showed disseminated microscopic calcifications within both testes (Figure 2 a, b). Tumor markers were within normal limits. At the time of bilateral herniorraphy cystoscopy was done: normal bladder and urethra and no Mullerian structures were found.

At the age of 4 -years the boy (Figure $3 a, b$ ) underwent one-stage correction of penoscrotal transposition (Figure 4 a, b). Postoperative period was uneventful. The cosmetic appearance of genitalia during the short-term follow-up (6 months) was acceptable (Figure $5 \mathrm{a}, \mathrm{b}$ ). 
Incomplete Penoscrotal Transposition in a Boy with Prenatally Diagnosed Klinefelter Syndrome: Case Presentation and Review of the Literature
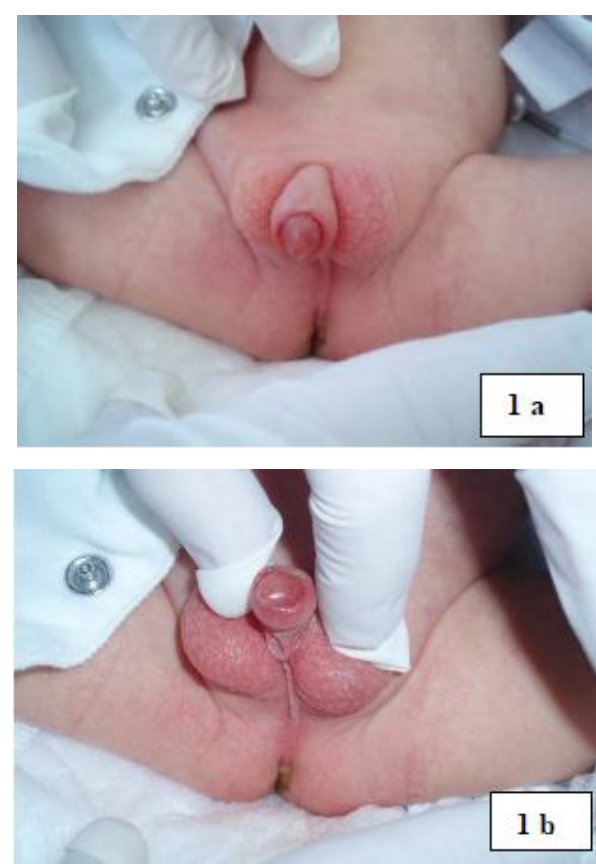

Figure1 (a, b). Incomplete penoscrotal transposition
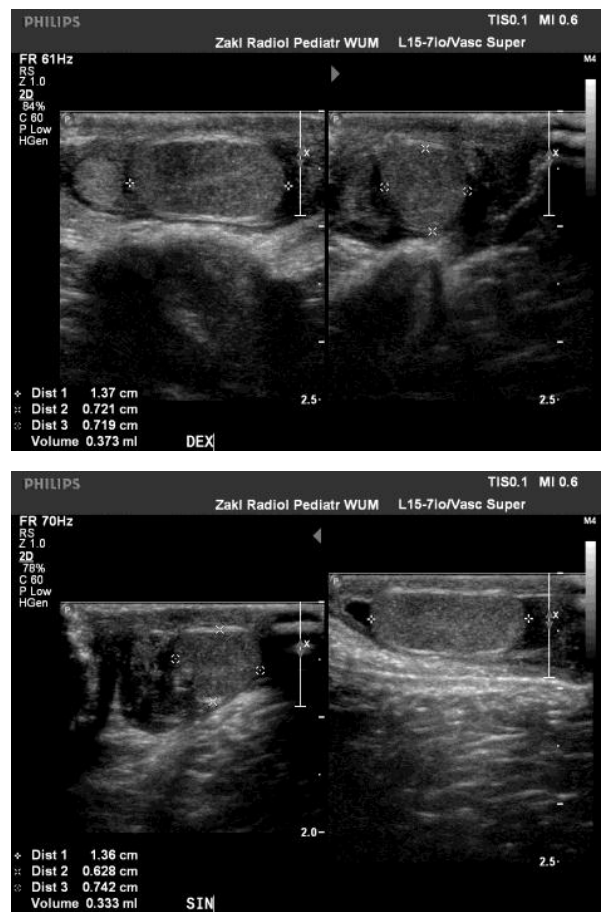

Figure2 (a, b). Ultrasound: disseminated microscopic calcifications within both testes

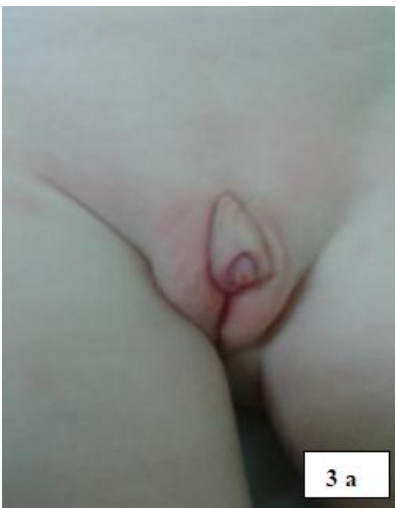

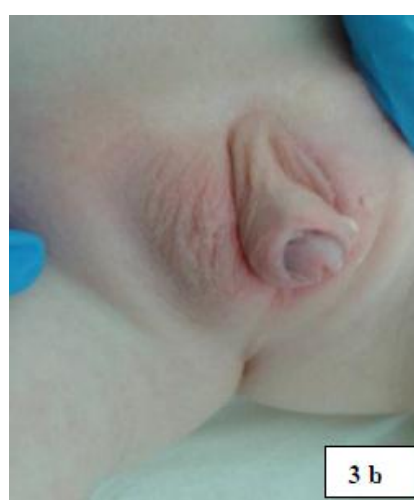

Figure3 (a, b). Preoperative view of incomplete penoscrotal transposition.
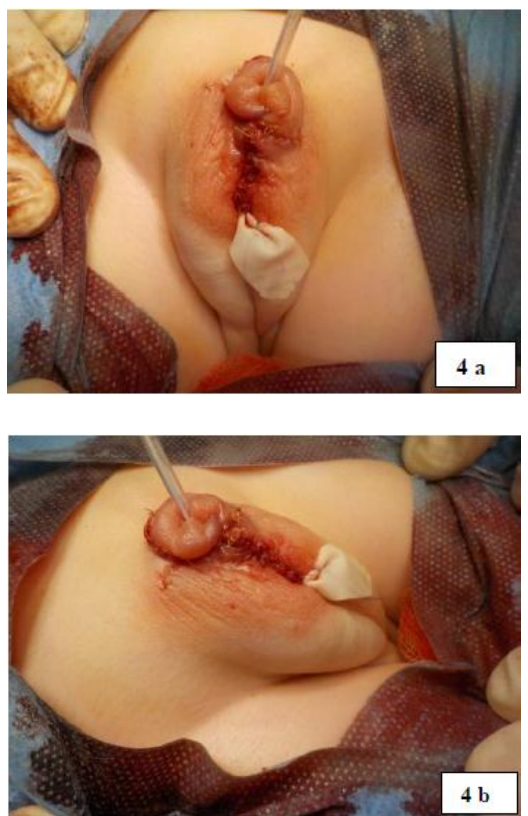

Figure4 (a, b). Scrotoplasty : intraoperative view
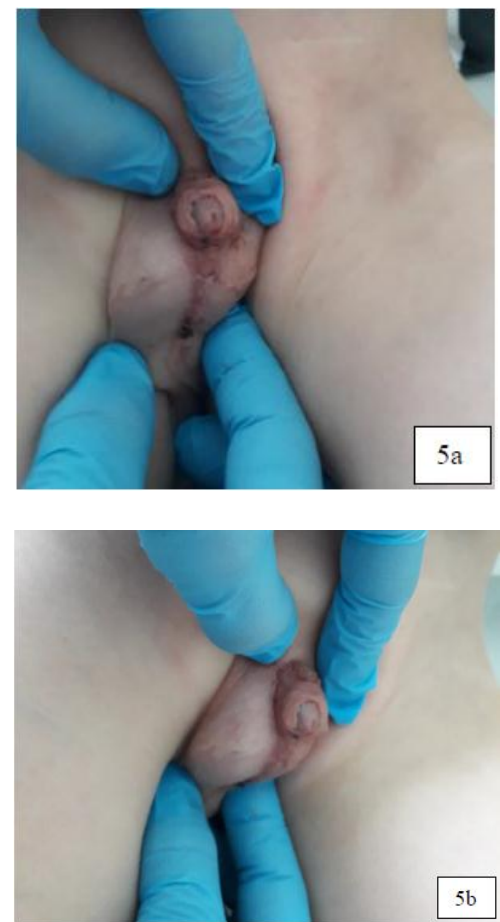

Figure5 (a, b). Postoperative view: two months after scrotoplasty 


\section{DISCUSSION}

Klinefelter patients classically have complete male sex differentiation and genital anomalies are generally not recognized as associated features of this syndrome $[1,2,3,4,5,6,7,8]$. In 2015 the extensive retrospective reviews of the literature for boys with Klinefelter syndrome and associated penoscrotal malformations, revelead only 16 such cases [9]. The described malformations included hypospadiasis, penile chordee, bifid scrotum and penoscrotal transposition. Penoscrotal transposition was noted in about one-third of collected cases. In those entire boys Klinefelter syndrome was diagnosed before puberty as a part of diagnostic workup for the presence of ambiguous genitalia.

Our patient presents an exceptional case of prenatally diagnosed Klinefelter syndrome because of suspicion of abnormal external genitalia and incomplete penoscrotal transposition was confirmed after the birth.

Penoscrotal transposition is a rare genital anomaly with wide spectrum of presentations $[10,11,12,13]$. In complete form of transposition the penis is located completely caudal to the scrotum and no scrotal tissue is present distally to the penis. In incomplete form scrotal tissue surround the root of the penis. Complete penoscrotal transposition usually occurs in conjuction with various forms of severe hypospadiasis: perineal, scrotal or penoscrotal. Other systemic abnormalities, including urinary tract as well as no genitourinary anomalies such as cardiac, gastrointestinal, craniofacial, central nervous system, growth deficiency and mental retardation are found up to $75 \%$ of patients with complete penoscrotal transposition $[10,11,12$, 13, 14, 15, 16, 17]. Incomplete transposition tends to present as isolated anomaly $[10,11$, 13]. In presented boy incomplete penoscrotal transposition, except Klinefelter syndrome and small VSD which resolved spontaneously, was the leading abnormality.

Various operative techniques of scrotoplasty have been described to correct penoscrotal transpostion [10, 11, 13]. In all of them the main goal of repair is relocating the penis superiorly and scrotum to a dependent position. In 1973 Glenn and Anderson published their technique for surgical correction of incomplete penoscrotal transposition [18], which is still in use with further modifications [19, 20]. In our patient scrotoplasty according to the technique presented by Glenn and Anderson was applied with good result.

Abnormal genitalia can be diagnosed prenatally as the result of ultrasound finding of abnormal external genitalia or discrepancy between fetal chromosome and phenotypic sex [21]. Prenatal sonographic features of penoscrotal transposition were described for the first time in the literature in 2002 [22], and then Wang et al. presented that prenatal diagnosis of penoscrotal transposition can be enable and facilitated with 2- and 3dimensional ultrasonography [23]. Also Klinefelter syndrome is more frequently diagnosed prenatally [24]. To our knowledge the case of prenatally diagnosed Klinefelter syndrome and penoscrotal malformation has not been described so far.

\section{REFERENCES}

[1] Nieschlag E, Ferlin A, Gravholt CH, Gromoll J, Kohler B, Lejeune H, Rogol AD, Wistuba J. The Klinefelter syndrome: current management and research challenges. Andrology. 2016; 4:545-549.

[2] Diamond DA, Yu RN. Sexual differentiation: normal and abnormal. In: In. Wein AJ, Kavoussi LR, Novick AC, Partin AW, Peters CA editors. Campbell-Walsh Urology 10th Edition, Elsevier, 2012:3597-3628.

[3] Manning MA, Hoyme HE. Diagnosis and management of the adolescent boy with Klinefelter syndrome. Adolesc Med. 2002; 13:367-374.

[4] Bojesen A, Gravholt CH. Klinefelter syndrome in clinical practice. Nat ClinPract Urol. 2007; 4:192-204.

[5] Pacenza N, Pasqualini T, Gottlieb S, Knoblovtis P, Costanzo PR, Usher JS, Rey RA, Martinez MP, Aszpis S. Clinical presentation of Klinefelter's syndrome: differences according to age. Int J Endocrinol. 2012, ID 324835; doi: $10.1155 / 2012 / 324835$.

[6] Nieschlag E. Klinefelter syndrome. The commonest form of hypogonadism, but often overlooked or untreated. DtschArztebl Int. 2013; 110:347-353.

[7] Lee YS, Cheng AWF, Ahmed SF, Shaw NJ, Hughes IA. Genital anomalies in Klinefelter's syndrome. Hormone Res. 2007; 68:150-155.

[8] Brandes BM, Mesrobian H-GO. Evaluation and management of genital anomalies in two patients with Klinefelter syndrome and review of literature. Urology.2005; 65:976-979.

[9] Hodhod A, Umurangwa F, El-Sherbiny M. Prepubertal diagnosis of Klinefelter syndrome due to penoscrotal malformations: case report 
and review of literature. Can UrolAssoc J. 2015; 9:e333-e336.

[10] Palmer JS. Abnormalities of the external genitalia in boys. In: Wein AJ, Kavoussi LR, Novick AC, Partin AW, Peters CA editors. Campbell-Walsh Urology 10th Edition, Elsevier, 2012:3537-3556.

[11] BakyFahmy MA, El Shennawy AAA, Edress AM. Spectrum of penoscrotal positional anomalies in children. Int J Surg. 2014; 12:983988.

[12] Pinke LA, Rathbun SR, Husmann DA, Kramer SA. Penoscrotal transposition: review of 53 patients. J Urol. 2001; 166:1865-1868.

[13] Park HJ. Penoscrotal transposition. In: Park N, Kim S, Moon D editors. Penile augmentation, Springer, Berlin, Heidelberg. 2016:269-272.

[14] Chadha R, Mann V, Sharma A, Bagga D. Complete penoscrotal transposition and associated malformations. PediatSurg Int. 1999; 15:505-507.

[15] Sexton P, Thomas JT, Petersen S, Brown N, Arms JE, Bryan J, Harraway J, Gardener G. Complete penoscrotal transposition: case report and review of the literature. Fetal DiagnTher. 2015; 37:70-74.

[16] Parida SK, Hall BD, Barton L, Fujimoto A. Penoscrotal transposition and associated anomalies: report of five cases and review of the literature. Am J Med Genet. 1995; 59:6875.

[17] Meguid NA, Temtamy SA, Mazen I. Transposition of external genitalia and associated malformations. ClinDysmorphol. 2003; 12:59-62.

[18] Glenn JF, Anderson EE. Surgical correction of incomplete penoscrotal transposition. J Urol. 1973; 110:603-605.

[19] Manjunath KN, Venkatesh MS. M-plasty for correction of incomplete penoscrotal transposition. World J Plast Surg. 2014; 3:138141.

[20] Saleh A. Correction of incomplete penoscrotal transposition by a modified Glenn-Anderson technique. Afr J Paediatr Surg. 2010; 7:181184.

[21] Chitayat D, Glanc P. Diagnostic approach in prenatally detected genital abnormalities. Ultrasound Obstet Gynecol. 2010; 35:637-646.

[22] Vijayaraghavan SB, Muruganand SK, Ravikumar VR, Marimuthu K. Prenatal sonographic features of penoscrotal transposition. J Ultrasound Med. 2002; 21:142 7-1430.

[23] Wang Y, Cai A, Sun J, Li T, Wang B, Li J. Prenatal diagnosis of penoscrotal transposition with 2- and 3-dimensional ultrasonography. J Ultrasound Med. 2011; 30:1397-1401.

[24] Dotters-Katz SK, Humphrey WM, Senz KL, Lee VR, Shaffer BL, Caughey AB. The impact of prenatally diagnosed Klinefelter syndrome on obstetric and neonatal outcomes. Eur J ObstetGynecolReprod Biol. 2016; 203:173176.

Citation: Teresa Dudek - Warchol, Stanislaw Warchol. Incomplete Penoscrotal Transposition in a Boy with Prenatally Diagnosed Klinefelter Syndrome: Case Presentation and Review of the Literature. ARC Journal of Pediatrics.2018; 4(2): 21-24. doi:dx.doi.org/10.20431/2455-5711.0402005.

Copyright: (c) 2018 Authors. This is an open-access article distributed under the terms of the Creative Commons Attribution License, which permits unrestricted use, distribution, and reproduction in any medium, provided the original author and source are credited. 